\title{
Characterization of a $\mathrm{Ca}^{2+}$ Uniporter from Bacillus subtilis by Partial Purification and Reconstitution into Phospholipid Vesicles
}

\author{
By IWAO KUSAKA* AND TAKU MATSUSHITA \\ Institute of Applied Microbiology, University of Tokyo, Bunkyo-ku, Yayoi 1-1-1, Tokyo, Japan
}

(Received 1 August 1986; revised 11 November 1986)

$\mathrm{Ca}^{2+}$ was accumulated by right-side-out membrane vesicles of Bacillus subtilis following imposition of a diffusion potential, inside-negative, owing to $\mathrm{K}^{+}$-efflux via valinomycin. Uptake was dependent on the magnitude of the membrane potential. This voltage-dependent $\mathrm{Ca}^{2+}$ uptake was inhibited by $\mathrm{Ca}^{2+}$ channel blockers such as nitrendipine, verapamil and $\mathrm{LaCl}_{3}$, and was competitively inhibited by $\mathrm{Ba}^{2+}$ and $\mathrm{Sr}^{2+}$. The system showed saturation kinetics with an apparent $K_{\mathrm{m}}$ for $\mathrm{Ca}^{2+}$ of about $250 \mu \mathrm{M}$. Proteins responsible for the voltagedependent $\mathrm{Ca}^{2+}$ uptake were partially purified by preparative isoelectric focusing in a Sepharose bed. A fraction at pH 5.28-5.33 contained the activity. The characteristics of $\mathrm{Ca}^{2+}$ uptake in reconstituted proteoliposomes were the same as those in membrane vesicles (sensitive to $\mathrm{Ca}^{2+}$ channel blockers; inhibited by $\mathrm{Ba}^{2+}$ and $\mathrm{Sr}^{2+}$ ). In addition, uptake was not influenced by a $\mathrm{pH}$ gradient imposed on the vesicles. The apparent $K_{\mathrm{m}}$ for $\mathrm{Ca}^{2+}$ in the reconstituted system was about $260 \mu \mathrm{M}$. The specific activity was increased about 50 -fold by purification with isoelectric focusing.

\section{INTRODUCTION}

The study of $\mathrm{Ca}^{2+}$ transport systems in bacterial cells has shown that $\mathrm{Ca}^{2+} / \mathrm{H}^{+}$and $\mathrm{Ca}^{2+} / \mathrm{Na}^{+}$ antiporters are responsible for extruding $\mathrm{Ca}^{2+}$ (Brey \& Rosen, 1979). Recently, we purified and characterized the antiporter from Bacillus subtilis (Matsushita et al., 1986). Conversely, the $\mathrm{Ca}^{2+}$ uptake system found in Azotobacter vinelandii (Zimniak \& Barnes, 1980) and Streptococcus faecalis (Kobayashi et al., 1978) was voltage (membrane-potential)-dependent.

$\mathrm{Ca}^{2+}$ is indispensable for sporulation in B. subtilis and Ordal (1977) reported that $\mathrm{Ca}^{2+}$ is required for the chemotactic response of this organism. Therefore, it is important to study the mechanism of $\mathrm{Ca}^{2+}$ uptake. Recently, a membrane-potential-dependent $\mathrm{Ca}^{2+}$ uptake system in $B$. subtilis was found by de Vrij et al. (1985). In this paper we describe the characterization and partial purification of the membrane protein responsible for transport.

\section{METHODS}

Preparation of right-side-out membrane vesicles. Bacillus subtilis W23 was grown in GYP medium (glucose, $1 \%$; yeast extract, $0.5 \%$; polypeptone, $0.5 \%$ ), and the cells were harvested in mid-exponential phase by centrifugation. The cells were washed once with $50 \mathrm{~mm}$-potassium phosphate buffer (pH 8.0). Right-side-out vesicles were prepared by the method described by Konings et al. (1973), and the final pellet was suspended in 50 mM-potassium phosphate buffer ( $\mathrm{pH} 6.8$ ).

Transport assay. $\mathrm{Ca}^{2+}$ uptake was driven by an artificial membrane potential. Membrane vesicles were suspended in $50 \mathrm{~mm}$-potassium phosphate buffer $\left(\mathrm{pH} \mathrm{6.8)}\right.$ containing $0.35 \mathrm{M}-\mathrm{K} \mathrm{Cl}$, and incubated at $45^{\circ} \mathrm{C}$ for 20 min (potassium loading). $\mathrm{MgCl}_{2}$ was then added (final concn $2.5 \mathrm{~mm}$ ) and the suspension was centrifuged at $105000 \mathrm{~g}$ for $30 \mathrm{~min}$; the pellet ( $\mathrm{K}^{+}$-loaded vesicles) was then suspended in $0.5 \mathrm{ml}$ of a solution containing $50 \mathrm{mM}$ sodium phosphate buffer ( $\mathrm{pH} \mathrm{6.8)}, 0.35 \mathrm{M}$-choline chloride, $2.5 \mathrm{mM}-\mathrm{MgCl}_{2}$ and $0.4 \mathrm{mM}^{-45} \mathrm{CaCl}_{2}$. The suspension

Abbreviations: FCCP, carbonyl cyanide $p$-trifluoromethoxyphenylhydrazone; TPMP ${ }^{+}$, triphenylmethylphosphonium ion. 
was incubated at $35^{\circ} \mathrm{C}$, and then the reaction was started by the addition of $1 \mu \mathrm{l}$ valinomycin $\left(1 \mathrm{mg} \mathrm{ml}^{-1}\right)$. At suitable time intervals, samples $(50 \mu \mathrm{l})$ were filtered through membrane filters $(0.45 \mu \mathrm{m}$ pore size; Toyo Science Co., Tokyo). Membrane vesicles on the filter were washed three times with $2.5 \mathrm{ml}$ of medium without ${ }^{45} \mathrm{CaCl}_{2}$. The radioactivity on the filter was measured with a gas flow counter. Binding of $\mathrm{Ca}^{2+}$ to the membrane vesicles, which reached a maximum value after $30 \mathrm{~s}$ at $35^{\circ} \mathrm{C}\left[0.50-0.60 \mathrm{nmol} \mathrm{Ca}^{2}\right.$ bound (mg membrane protein) $\left.{ }^{-1}\right]$ was subtracted from the total uptake value. Initial rates of transport were estimated and expressed as $\mathrm{nmol}^{\mathrm{Ca}^{2+}}$ transported $\min ^{-1}$ (mg protein) ${ }^{-1}$.

Preparation of membrane protein. Membrane proteins were prepared as described by Matsushita et al. (1986). In B. subtilis, membrane proteins are released from the membrane and accumulated in the cells as water-insoluble protein aggregates during membrane autolysis (Kusaka et al., 1976).

Cells (wet wt $10 \mathrm{~g}$ ) were suspended in $0.1 \mathrm{M}$-sodium phosphate buffer ( $\mathrm{pH} 6.8$; total vol. $250 \mathrm{ml}$ ) containing $1 \mathrm{mM}-\mathrm{ZnCl}_{2}$ and lysozyme $\left(150 \mu \mathrm{g} \mathrm{ml}^{-1}\right)$. After about $2 \mathrm{~h}$ incubation at $37^{\circ} \mathrm{C} \mathrm{DNAase}(0.5 \mathrm{mg})$ was added and the lysate was centrifuged at $40000 \mathrm{~g}$ for $25 \mathrm{~min}$. The pellet (membrane protein aggregates) was washed once with $25 \mathrm{~mm}$-Tris/ $\mathrm{H}_{2} \mathrm{SO}_{4}$ (pH 7.2) and suspended in the same buffer containing $6 \mathrm{M}$-urea (final vol. $100 \mathrm{ml}$ ). The suspension was incubated in an ice-bath for $3 \mathrm{~h}$ to permit solubilization by urea, and then centrifuged at $156000 \mathrm{~g}$ for $2 \mathrm{~h}$. The released membrane proteins were recovered in the supernatant.

Preparative isoelectric focusing. Preparative isoelectric focusing in Sepharose CL-6B (Pharmacia) using a flatbed apparatus FBE 3000 (Pharmacia) was done as described by Radola (1974). About 50 mg protein was mixed with $30 \mathrm{ml}$ Sepharose CL-6B and $2.5 \mathrm{ml}$ Pharmalyte (pI 4.0-6.5; Pharmacia; 40\%, v/v). After $12 \mathrm{~h}$ electrophoresis, the gel was scraped from the bed, divided into 20 fractions, and eluted with $6 \mathrm{~mm}$ urea. Voltagedependent $\mathrm{Ca}^{2+}$ uptake activity was found in the fractions between $\mathrm{pH} 5 \cdot 20-5 \cdot 40$. For further purification, the gel (pH 5.20-5.40; a total of $2.2 \mathrm{mg}$ protein in $3.5 \mathrm{ml}$ gel) was transferred into a small trough $(1.0 \times 1.0 \mathrm{~cm} ; 6 \mathrm{~cm}$ long) and isoelectric focusing was repeated for another $12 \mathrm{~h}$. After electrophoresis, the gel was cut into 10 equal portions and protein was eluted with $1.0 \mathrm{ml} 25 \mathrm{~mm}$-Tris/ $\mathrm{H}_{2} \mathrm{SO}_{4}(\mathrm{pH} \mathrm{7.2)}$ containing $6 \mathrm{M}$-urea. The eluted protein was salted out by the addition of $0.55 \mathrm{~g}$ solid $\left(\mathrm{NH}_{4}\right)_{2} \mathrm{SO}_{4}$ to $1 \mathrm{ml}$ of protein solution (above $80 \%$ saturation) and $\mathrm{Ca}^{2+}$ uptake activity was estimated.

Formation of proteoliposomes and assay of transport activity. Proteins $(5-10 \mu \mathrm{g})$ and asolectin $(6 \mathrm{mg})$ were mixed in $25 \mathrm{~mm}-\mathrm{Tris} / \mathrm{H}_{2} \mathrm{SO}_{4}(\mathrm{pH} 7 \cdot 2)$ containing $0.4 \mathrm{M}-\mathrm{KCl}$ and sonicated for $2 \mathrm{~min}(10 \mathrm{kHz}, 100 \mathrm{~W})$ at room temperature. Then $\mathrm{MgCl}_{2}$ was added (final concn $2.5 \mathrm{mM}$ ) and the sonicate was centrifuged at $105000 \mathrm{~g}$ for $30 \mathrm{~min}$. The pellet was suspended in $0.5 \mathrm{ml}$ of a solution containing $25 \mathrm{mM}-\mathrm{Tris} / \mathrm{H}_{2} \mathrm{SO}_{4}(\mathrm{pH} \mathrm{7.2)}, 0.4 \mathrm{M}$-choline chloride, $2.5 \mathrm{mM}$ $\mathrm{MgCl}_{2}$ and $0.4 \mathrm{~mm}^{-45} \mathrm{CaCl}_{2} \cdot \mathrm{Ca}^{2+}$ uptake was started by the addition of valinomycin (final concn $1 \mu \mathrm{g} \mathrm{ml}^{-1}$ ) at $30^{\circ} \mathrm{C}$. The other methods were the same as those for the assay of transport in membrane vesicles. Binding of $\mathrm{Ca}^{2+}$ to the proteoliposomes (about $80 \mathrm{pmol} \mathrm{Ca}^{2+}$ was bound to $1 \mathrm{mg}$ asolectin) was subtracted from the total uptake value. The initial rate of transport was estimated and expressed as $\mathrm{nmol} \mathrm{Ca}^{2+} \mathrm{min}^{-1}$ (mg protein) $)^{-1}$.

Protein determination. This was by the Lowry method.

Chemicals. ${ }^{45} \mathrm{CaCl}_{2}\left[18 \mu \mathrm{Ci} \mu \mathrm{mol}^{-1} ;\left(666 \mathrm{kBq} \mu \mathrm{mol}^{-1}\right)\right]$ was purchased from New England Nuclear; all other reagents were of analytical grade.

SDS-PAGE. The method of Laemmli (1970) was used.

\section{RESULTS}

\section{$\mathrm{Ca}^{2+}$ uptake by right-side-out membrane vesicles}

Right-side-out membrane vesicles of $B$. subtilis accumulated $\mathrm{Ca}^{2+}$ in the presence of $20 \mathrm{mM}$ ascorbate and $0.1 \mathrm{mM}$-phenazinemethosulphate as an electron donor system. Uptake was inhibited by the uncoupler FCCP $(2 \mu \mathrm{M})$, but not by the electroneutral $\mathrm{K}^{+} / \mathrm{H}^{+}$exchanger nigericin (data not shown), indicating that the membrane potential was the driving force for $\mathrm{Ca}^{2+}$ uptake in the vesicles, as reported by de Vrijet al. (1985). This conclusion was supported by $\mathrm{Ca}^{2+}$ uptake experiments using membrane vesicles on which artificial membrane potentials were imposed. A $\mathrm{K}^{+}$-diffusion membrane potential, inside-negative, was generated in $\mathrm{K}^{+}$loaded vesicles by the addition of valinomycin. This potential drove $\mathrm{Ca}^{2+}$ uptake into the vesicles by a process that was inhibited (Fig. 1) by the membrane-permeant cation TPMP+.

The rate of $\mathrm{Ca}^{2+}$ uptake by the vesicles (estimated from the initial velocity of uptake) was measured over a range of membrane potentials generated by the establishment of a $\mathrm{K}^{+}$gradient across the membrane in the presence of valinomycin. $\mathrm{K}^{+}$-loaded vesicles $\left(0.4 \mathrm{M}\right.$-internal $\mathrm{K}^{+}$ concn) were suspended in solutions containing various concentrations of $\mathrm{KCl}$. The rate of $\mathrm{Ca}^{2+}$ uptake was proportional to $\log \left(\left[\mathrm{K}^{+}\right]_{\text {in }} /\left[\mathrm{K}^{+}\right]_{\text {out }}\right.$ ) (Fig. 2). The membrane potentials generated by 


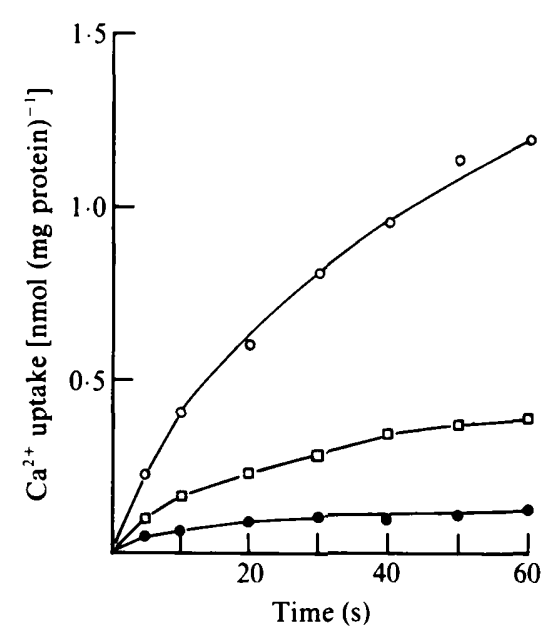

Fig. 1

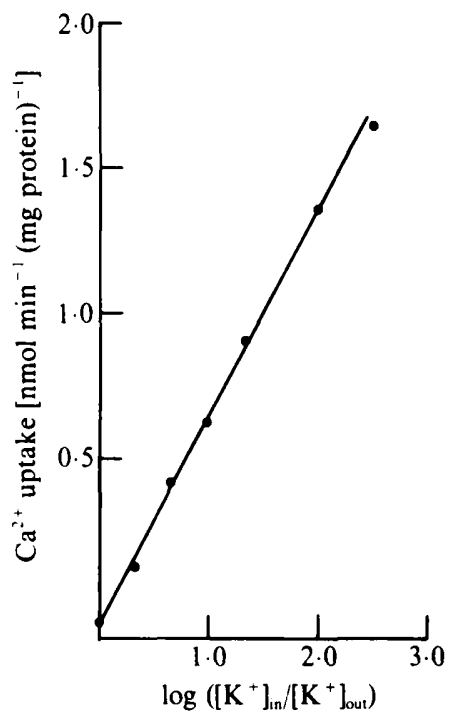

Fig. 2

Fig. 1. $\mathrm{Ca}^{2+}$ uptake driven by a $\mathbf{K}^{+}$-diffusion potential in right-side-out vesicles of $\mathbf{B}$. subtilis. $\mathbf{K}^{+-}$ loaded vesicles (1 mg protein) were suspended in $0.5 \mathrm{ml} 50 \mathrm{~mm}$-sodium phosphate buffer (pH 6.8) containing $0.35 \mathrm{M}$-choline chloride (O), plus $1 \mathrm{mM}-\mathrm{TPMP}^{+}(\square)$. Uptake was initiated by the addition of $1 \mu \mathrm{g}$ valinomycin. Valinomycin was not added in the control experiment $(\bullet)$. All the experiments were done in the presence of $0.4 \mathrm{mM}^{-45} \mathrm{CaCl}_{2}$ and $2.5 \mathrm{mM}-\mathrm{MgCl}_{2}$ as described in Methods.

Fig. 2. Voltage-dependency of $\mathrm{Ca}^{2+}$ uptake in right-side-out vesicles of $\boldsymbol{B}$. subtilis. $\mathbf{K}^{+}$-loaded vesicles were suspended in $0.5 \mathrm{ml} 50 \mathrm{~mm}$-sodium phosphate buffer (pH 6.8) containing various $\mathrm{K}^{+}$ concentrations $(1,4,20,40,100,200$ and $400 \mathrm{mM})$; the final cation concentration in the reaction mixture was adjusted to $0.4 \mathrm{M}$ with choline chloride. All the experiments were done in the presence of $0.4 \mathrm{mM}$ ${ }^{45} \mathrm{CaCl}_{2}$ and $2 \cdot 5 \mathrm{mM}-\mathrm{MgCl}_{2}$.

Table 1. Effect of $\mathrm{Ca}^{2+}$ channel blockers on the voltage-dependent $\mathrm{Ca}^{2+}$ uptake system in B. subtilis

$\begin{array}{lc}\begin{array}{l}\mathrm{Ca}^{2+} \text { channel } \\ \text { blocker }\end{array} & \begin{array}{c}\text { Concn } \\ (\mu \mathrm{M})\end{array} \\ \text { None } & - \\ \text { Nitrendipine } & 1.0 \\ & 10 \cdot 0 \\ \text { Verapamil } & 25.0 \\ & 50.0 \\ \mathrm{LaCl}_{3} & 100 \cdot 0 \\ & 250.0\end{array}$

$$
\begin{gathered}
\text { Uptake activity } \\
{\left[\mathrm{nmol} \mathrm{Ca}{ }^{2+} \min ^{-1}(\mathrm{mg} \text { protein })^{-1}\right]}
\end{gathered}
$$

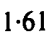

$0 \cdot 61$

$0 \cdot 22$

$1 \cdot 01$

0.65

0.28

0.05

\section{Percentage} of control

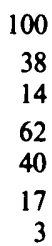

$\mathrm{K}^{+}$-diffusion, and estimated from changes in fluorescence of the dye 3,3'-dipropylthiodicarbocyanine $\left[\right.$ diS- $\left.\mathrm{C}_{3}-(5)\right]$ (Waggoner, 1976), were proportional to $\log \left(\left[\mathrm{K}^{+}\right]_{\text {in }} /\left[\mathrm{K}^{+}\right]_{\text {out }}\right.$ ) (data not shown). Therefore, the rate of uptake of $\mathrm{Ca}^{2+}$ (Fig. 2) was dependent on the magnitude of the membrane potential (voltage). It is well-known that $\mathrm{Ca}^{2+}$ flux through voltage-dependent $\mathrm{Ca}^{2+}$ channels in animal excitable membranes is inhibited by blockers such as nitrendipine, verapamil and $\mathrm{LaCl}_{3}$. Therefore, we investigated the effect of these drugs on $\mathrm{Ca}^{2+}$ uptake by membranes of $B$. subtilis. Uptake was driven by $\mathrm{K}^{+}$-diffusion potentials and was inhibited by all of these drugs, though verapamil was not so effective as nitrendipine (Table 1).

$\mathrm{Ca}^{2+}$ uptake showed saturation kinetics and a Lineweaver-Burk plot of the data (not shown) indicated a $K_{\mathrm{m}}$ for $\mathrm{Ca}^{2+}$ of about $250 \mu \mathrm{M}$. Uptake was competitively inhibited by $\mathrm{Ba}^{2+}$ and $\mathrm{Sr}^{2+}$, and $K_{\mathrm{i}}$ was calculated to be $930 \mu \mathrm{M}$ for $\mathrm{Ba}^{2+}$ and $370 \mu \mathrm{M}$ for $\mathrm{Sr}^{2+}$. 


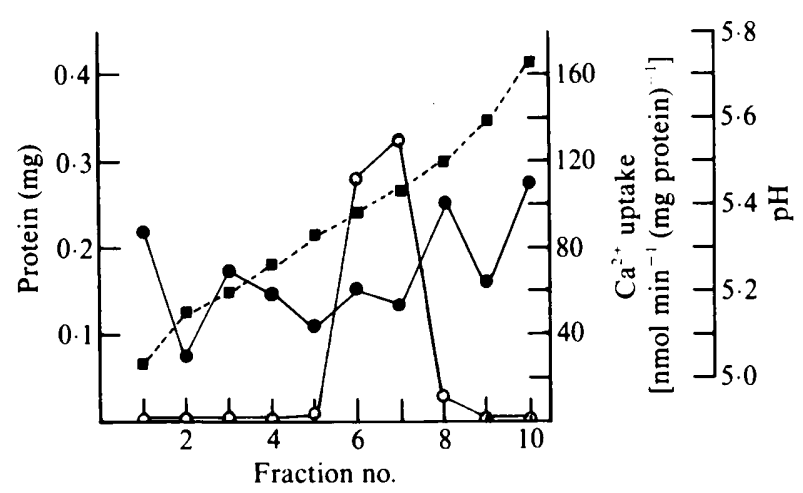

Fig. 3. Patterns of protein distribution after the second isoelectric focusing on Sepharose CL-6B. The $\mathrm{pH} 5 \cdot 20-5 \cdot 40$ fraction from the first isoelectric focusing $(\mathrm{pH} 4 \cdot 0-6.5)$ was isolated and isoelectric focusing was repeated in a small trough for another $12 \mathrm{~h}$. Gels were cut into 10 fractions and protein was estimated in each fraction. 9 . Protein; $\mathbf{D}, \mathrm{pH} ; \mathrm{O}, \mathrm{Ca}^{2+}$ uptake activity.

\section{Isolation and reconstitution of the protein responsible for the voltage-dependent $\mathrm{Ca}^{2+}$ uptake system}

Membrane proteins $(110 \mathrm{mg})$ released during membrane autolysis of $B$. subtilis were dissolved in $50 \mathrm{ml} 25 \mathrm{mM}$-Tris/ $\mathrm{H}_{2} \mathrm{SO}_{4}(\mathrm{pH} 7 \cdot 2)$ containing $6 \mathrm{M}$-urea, and subjected to $\left(\mathrm{NH}_{4}\right)_{2} \mathrm{SO}_{4}$ fractionation. The fraction precipitated at $35-55 \%(\mathrm{w} / \mathrm{v})$ saturation (active fraction) was isolated by centrifugation. The pellet (about $50 \mathrm{mg}$ ) was dissolved in $2.5 \mathrm{ml}$ distilled water and dialysed against 21 distilled water. Solid urea was added to the retentate to give a urea concentration of $6 \mathrm{M}$ (final volume was about $4 \mathrm{ml}$ and the $\mathrm{pH}$ of solution was 6.4). The protein solution was mixed with $30 \mathrm{ml}$ semi-dried Sepharose CL-6B and Pharmalyte (final concn $3.3 \%$, $\mathrm{v} / \mathrm{v} ; \mathrm{pI} 4 \cdot 0-6 \cdot 5)$ and subjected twice to isoelectric focusing (Fig. 3). Voltage-dependent $\mathrm{Ca}^{2+}$ uptake activity was found after reconstitution of the fractions at $\mathrm{pH} 5 \cdot 28-5 \cdot 33$ (see below). SDSPAGE of these fractions revealed six protein components with molecular masses of 64,47 (major protein), 42, 36 (major), 32 and $20 \mathrm{kDa}$ (Fig. 4). Further purification is needed to obtain a homogeneous preparation of the $\mathrm{Ca}^{2+}$ uptake system.

Proteins of pI 5.28-5.33 (5-10 $\mu \mathrm{g})$ were reconstituted into asolectin $(6 \mathrm{mg})$ liposomes. $\mathrm{Ca}^{2+}$ uptake into these proteoliposomes could be driven by a membrane potential, inside negative, generated by $\mathrm{K}^{+}$-diffusion in the presence of valinomycin. Specific activity was increased about 50 -fold by the second isoelectric focusing [125 $\left.\mathrm{nmol} \mathrm{Ca}^{2+} \min ^{-1}(\mathrm{mg} \text { protein })^{-1}\right]$.

Bacterial nutrient transport is of ten coupled to $\mathrm{H}^{+}$flux ; therefore we studied the effect of a $\mathrm{pH}$ gradient on $\mathrm{Ca}^{2+}$ uptake. The gradient was imposed on $\mathrm{K}^{+}$-loaded vesicles and voltagedependent uptake was started by the addition of valinomycin. Uptake was inhibited at $\mathrm{pH}$ values under 5.0 and above 8.5 . In addition, proteoliposomes were formed in $25 \mathrm{mM}$ Tris/ $\mathrm{H}_{2} \mathrm{SO}_{4}, \mathrm{pH} 8.0$ (pH 8.0 vesicles) or $25 \mathrm{mM}-\mathrm{MES} / \mathrm{Tris}$, $\mathrm{pH} 5.5$ (pH 5.5 vesicles); $\mathrm{pH} 8.0$ vesicles were then suspended in $25 \mathrm{mM}-\mathrm{MES} / \mathrm{Tris}(\mathrm{pH} 5.5)$ and $\mathrm{pH} 5.5$ vesicles were suspended in $25 \mathrm{~mm}-\mathrm{Tris} / \mathrm{H}_{2} \mathrm{SO}_{4}$ (pH 8.0). $\mathrm{Ca}^{2+}$ uptake was not influenced by these $\mathrm{pH}$ gradients (the results for $\mathrm{pH} 8.0$ vesicles are shown in Fig. 5).

Uptake activity in the proteoliposomes was inhibited $62 \%$ by $10 \mu \mathrm{M}$-nitrendipine, $40 \%$ by $25 \mu \mathrm{M}$-verapamil, $88 \%$ by $100 \mu \mathrm{M}-\mathrm{LaCl}_{3}, 50 \%$ by $1 \mathrm{~mm}-\mathrm{BaCl}_{2}$ and $75 \%$ by $1 \mathrm{mM}^{-\mathrm{SrCl}_{2}}$ (Fig. 5 ). This effect was comparable to those found in the membrane vesicles (see Table 1).

The $K_{\mathrm{m}}$ for $\mathrm{Ca}^{2+}$ in the reconstituted system was about $260 \mu \mathrm{M}$, which is close to the value for the membrane vesicles.

\section{DISCUSSION}

$\mathrm{Ca}^{2+}$ uptake in B. subtilis was studied extensively by de Vrij et al. (1985). The results in the present paper agree with their work. We have further characterized the transport system and shown it to be sensitive to $\mathrm{Ca}^{2+}$ channel blockers of animal excitable membranes. 


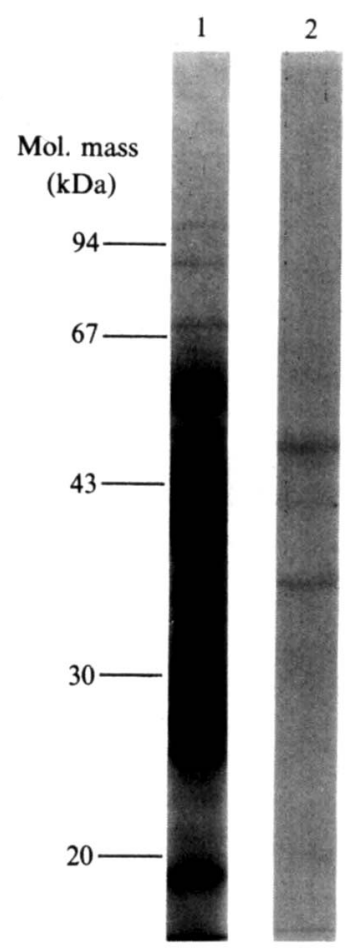

Fig. 4

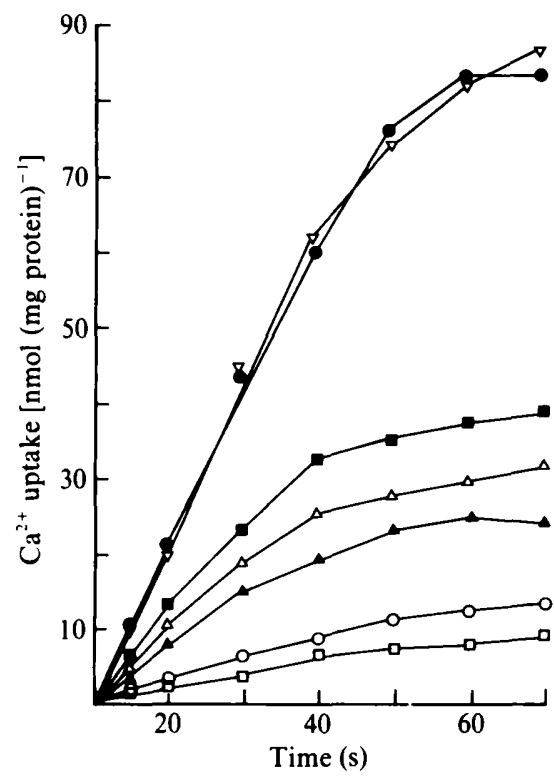

Fig. 5

Fig. 4. SDS-PAGE of membrane protein and partially purified $\mathrm{Ca}^{2+}$ uniporter (pI 5.28-5-33). Proteins were stained with Coomassie blue. Molecular mass standards are indicated on the left. Lane 1, initial membrane protein; lane 2 , pI 5.28-5.33 fraction.

Fig. 5. $\mathrm{Ca}^{2+}$ uptake driven by a $\mathrm{K}^{+}$-diffusion potential in proteoliposomes containing the $\mathrm{pH} 5 \cdot 28-5 \cdot 33$ fraction. $\mathrm{K}^{+}$-loaded proteoliposomes $\left(5-10 \mu \mathrm{g}\right.$ protein) were suspended in $25 \mathrm{mM}$-Tris/ $\mathrm{H}_{2} \mathrm{SO}_{4}(\mathrm{pH} 7 \cdot 2)$ containing $0.4 \mathrm{M}$-choline chloride. Uptake was initiated by addition of $1 \mu \mathrm{g}$ valinomycin. Inhibitors added were nitrendipine $(10 \mu \mathrm{M}, \Delta)$; verapamil $(25 \mu \mathrm{M}, \mathbf{\square}) \mathrm{LaCl}_{3}(100 \mu \mathrm{M}, \square) ; \mathrm{BaCl}_{2}(1 \mathrm{mM}, \Delta)$ or $\mathrm{SrCl}_{2}(1 \mathrm{mM}, \mathrm{O})$. O, No inhibitor added. Uptake activity was also assayed in $\mathrm{K}^{+}$-loaded proteoliposomes in which a $\mathrm{pH}$ gradient, inside alkaline, was imposed $(\nabla)$.

Membrane proteins in $B$. subtilis were readily released during membrane autolysis and isolated as water-insoluble protein aggregates. Using this membrane protein as a starting material, we partially purified a voltage-dependent $\mathrm{Ca}^{2+}$ uptake system. This system was further characterized by reconstitution into liposomes, and the sensitivity of $\mathrm{Ca}^{2+}$ uptake to $\mathrm{Ca}^{2+}$ channel blockers was confirmed. The sample was not homogenous, and comprised six protein components as shown by SDS-PAGE. The activity was stable during purification in $6 \mathrm{M}$-urea : therefore, membrane protein isolation by the present method could be used for further purification in future work.

$\mathrm{Ca}^{2+}$ uptake into the reconstituted proteoliposomes was not influenced by a $\mathrm{pH}$ gradient, and appeared to depend only on the membrane potential: therefore, the $\mathrm{Ca}^{2+}$ uptake system may be a voltage-dependent uniporter.

The inhibitory effect of the $\mathrm{Ca}^{2+}$ channel blockers, especially nitrendipine, was an interesting pointer for future studies.

\section{REFERENCES}

Brey, R. N. \& Rosen, B. P. (1979). Cation/proton antiport systems in Escherichia coli. Properties of the calcium/proton antiporter. Journal of Biological Chemistry 254, 1957-1963.
Kobayashi, H., van Brunt, J. \& Harold, F. M. (1978). ATP-linked calcium transport in cells and membrane vesicles of Streptococcus faecalis. Journal of Biological Chemistry 253, 2085-2092. 
Konings, W. N., Bisschop, A., VeenhuIs, M. \& VeRMEULEN, C. A. (1973). New procedure for the isolation of membrane vesicles of Bacillus subtilis and an electron microscopy study of their ultrastructure. Journal of Bacteriology 116, 1456-1465.

Kusaka, I., Hayakawa, K., Kanai, K. \& Fukui, S. (1976). Isolation and characterization of hydrophobic proteins ( $\mathrm{H}$ proteins) in the membrane fraction of Bacillus subtilis. European Journal of Biochemistry 71, $451-458$.

LAEMMLI, U. K. (1970). Cleavage of structural proteins during the assembly of the head of bacteriophage T4. Nature, London 227, 680-685.

Matsushita, T., Ueda, T. \& Kusaka, I. (1986) Purification and characterization of $\mathrm{Ca}^{2+} / \mathrm{H}^{+}$antiporter from Bacillus subtilis. European Journal of Biochemistry 156, 95-100.
ORDAL, G. W. (1977). Calcium ion regulates chemotactic behaviour in bacteria. Nature, London 270, 66-67.

RADOLA, R. J. (1974). Isoelectric focusing in layers of granulated gels. II. Preparative isoelectric focusing. Biochimica et biophysica acta 386, 181-195.

de VriJ, W., Bulthuis, R., Postma, E. \& Konings, W. N. (1985). Calcium transport in membrane vesicles of Bacillus subtilis. Journal of Bacteriology 164, 1294-1300.

WAGGONER, A. (1976). Optical probes of membrane potential. Journal of Membrane Biology 27, 317-334.

ZIMNIAK, P. \& BARNES, E. M., JR (1980). Characterization of a calcium/proton antiporter and an electrogenic calcium transporter in membrane vesicles from Azotobacter vinelandii. Journal of Biological Chemistry 255, 10140-10143. 